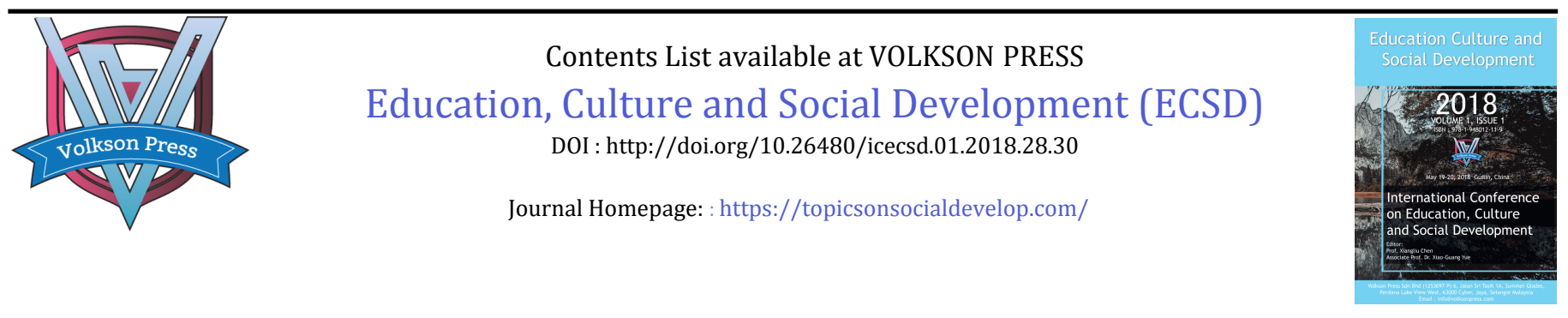

\title{
APPLICATION OF DISCIPLINE-INTEGRATED PBL TEACHING METHOD IN MEDICAL EXAMINATION OF MEDICAL COLLEGES
}

\author{
Wang Fei \\ Nanyang Medical College, Nanyang City, Henan Province, China. \\ *Corresponding author email:245076979@qq.com
}

This is an open access article distributed under the Creative Commons Attribution License, which permits unrestricted use, distribution, and reproduction in any medium, provided the original work is properly cited

\section{ARTICLE DETAILS}

\section{Article History:}

Received 12 November 2017 Accepted 12 December 2017 Available online 1 January 2018

\section{ABSTRACT}

To explore the application of disciplinary integrated PBL teaching method in the teaching of microbiological examination of medical examination subjects in medical colleges. One hundred and eight students in two classes in the medical examination department of a medical college were divided into two groups. One group used PBL teaching mode and one group implemented traditional teaching mode. SPSS22.0 software was used to analyze the learning effect of the two groups of students and the satisfaction of the teaching model. The differences in teaching quality and teaching effect under the two modes were analyzed. The students who adopted the PBL teaching model obviously favored the traditional non-PBL teaching mode in the satisfaction survey and the outstanding rate of academic performance.

\section{KEYWORDS}

Medical Education, Teaching Methods, PBL, Microbiological Testing.

\section{INTRODUCTION}

Problem-based learning PBL (Problem-based Learning) teaching method is a new type of teaching method widely used in medical colleges and universities today. It is based on problem-based, student-centered, teacher-oriented group discussion-based teaching methods [1]. By allowing students to jointly solve complex and practical problems in the form of group cooperation, they learn the scientific knowledge underlying the problem. The classic method of implementation is: Ask Questions Collect Information - Group Discussion - Class Discussion - Teacher Summary. In medical education, PBL can not only enable students to master basic knowledge, but also improve students' ability of independent learning, teamwork, practical innovation and critical thinking.

The traditional teaching goal is to impart the ready-made knowledge to the students and give priority to teachers' teaching. The basic concepts and principles in the course are emphasized. Even after the computer teaching reform, the case teaching used by the schools is still taught by the teachers in the project teaching. Steps, basic concepts taught to studentsbased teaching model. PBL can effectively improve students' learning interest and motivation, help students form a spontaneous learning attitude, and can improve their ability to solve problems, learn independently, creative thinking and collaborative learning, thus laying a solid foundation for lifelong learning [2]. Traditional teaching mode and PBL teaching mode have their own unique features.
Table 1: Comparison between traditional teaching mode and PBL teaching mode

\begin{tabular}{|c|c|c|}
\hline Category & PBL teaching mode & $\begin{array}{l}\text { Traditional teaching } \\
\text { mode }\end{array}$ \\
\hline $\begin{array}{l}\text { Knowledge } \\
\text { acquisition method }\end{array}$ & $\begin{array}{l}\text { Autonomous } \\
\text { learning, group } \\
\text { collaborative } \\
\text { learning, students' } \\
\text { active participation }\end{array}$ & $\begin{array}{l}\text { Teaching, students } \\
\text { passively accept }\end{array}$ \\
\hline $\begin{array}{l}\text { The main body of } \\
\text { teaching }\end{array}$ & Student-centered & Teacher-centered \\
\hline The core of teaching & problem & Textbook system \\
\hline $\begin{array}{l}\text { The way the } \\
\text { question was asked }\end{array}$ & $\begin{array}{l}\text { Face to face, } \\
\text { collaborative } \\
\text { communication } \\
\text { platform, various } \\
\text { network } \\
\text { communication } \\
\text { tools }\end{array}$ & $\begin{array}{l}\text { Face to face, } \\
\text { collaborative } \\
\text { communication } \\
\text { platform, }\end{array}$ \\
\hline $\begin{array}{l}\text { Teaching } \\
\text { effectiveness test }\end{array}$ & $\begin{array}{l}\text { Exchange of results, } \\
\text { open competition }\end{array}$ & $\begin{array}{l}\text { Review, } \\
\text { Examination }\end{array}$ \\
\hline $\begin{array}{l}\text { Teaching focus } \\
\text { Communication } \\
\text { between classmates }\end{array}$ & $\begin{array}{ll}\text { Ability training } & \\
\text { Provides } & \text { an } \\
\text { environment } & \text { for } \\
\text { communication } & \end{array}$ & $\begin{array}{l}\text { Accept knowledge } \\
\text { Non-conversational } \\
\text { awareness }\end{array}$ \\
\hline
\end{tabular}

\section{PBL TEACHING METHOD PATTERN INTRODUCTION}

With the rapid development of social science and technology and education, various problems that have constrained the promotion of the PBL teaching method have been continuously solved. In addition, the innovation and development of medical education has also accelerated the application and promotion of PBL. 


\subsection{PBL Teaching Development}

The education reform has promoted the maturity of the PBL application environment. Since the education reform centered on "quality education" has been introduced, a variety of foreign education theories and literature have been introduced and translated into China. Educational institutions have vigorously promoted "quality education" and teacher training, and domestic counterparts have more References and exchanges have promoted the research and practice of PBL localization [3]. In addition, education reform has also promoted the improvement of students' ability to learn independently. The quality of students and the purpose of learning are more self-conscious, and they promote the students' active learning and independent learning and the cultivation of independent thinking ability.

The transformation of modern medical model objectively requires the application of PBL teaching. The "biological-psychological-societyenvironmental" modern medical model has been promoted and applied [4]. This requires medical colleges and universities to focus on cultivating students' professional knowledge and comprehensive quality. The traditional teaching model has become increasingly difficult to meet the needs of society. This promotes the smooth promotion of the PBL teaching model.

The globalization of medical education standards and content requires us to study the mature medical education models abroad. With the acceleration of internationalization, in order to standardize and effectively improve the quality of medical education in China, the Ministry of Education has explicitly proposed to adopt internationally accepted standards to regulate linear medical education in China. This kind of environment promotes the application of foreign advanced PBL teaching in the medical education field in China.

\subsection{Implementation of PBL Teaching Model}

\subsubsection{Internal PBL teaching}

This curriculum design based on scientific research and clinical issues has changed the boundaries of traditional disciplines, reintegrated the knowledge of different disciplines, rebuilt new knowledge systems, and solved the teaching problems. However, it limits the learners' ideas and methods of solving problems. It is difficult for learners to integrate the knowledge of different disciplines, and it is difficult to effectively solve practical problems in scientific research and clinical practice.

\subsubsection{The combination of PBL teaching mode and traditional teaching mode}

The traditional teaching model is learning based on "teaching". It is the teacher who provides information and knowledge to students and requires students to remember so as to achieve the purpose of learning. In this process, teachers are the leading students and students are passively accepted [5]. The PBL teaching model is based on questions, studentcentered, and teacher-oriented group discussion-based teaching methods. However, because China's education system and teaching process are quite different from those in foreign countries, the implementation of PBL teaching still faces some difficulties. At present, most medical colleges combine PBL and LBL teaching methods in teaching to obtain better teaching effects and expected teaching objectives. At the same time, they also improve students' enthusiasm for learning and initiative.

\subsubsection{The PBL teaching model is combined with a case-based teaching model}

The combination of the PBL teaching model and the case-based teaching model is a brand-new teaching model based on problem-based learning development. The teaching forms are various. The core of the teaching model is the clinical case-based, problem-based group. Discussion pedagogy. This teaching mode is mainly used in the teaching of clinical courses. The PBL teaching method is combined with case-based teaching mode. The whole teaching process is lively and lively, and ultimately achieves the purpose of teaching.

\subsubsection{Discipline-integrated PBL teaching model}

Discipline-integrated PBL teaching model Subject-integrated PBL teaching is designed on the basis of full consideration of the existing teaching conditions: On the basis of preserving the original curriculum system, an independent "multi-disciplinary joint teaching" course is added, and the teaching method is completely completed. The standard PBL small class discussion mode is adopted as a useful supplement to the traditional teaching mode to cultivate students' abilities and qualities in various aspects. Discipline-integrated PBL teaching needs to solve several problems: (1) Leading a discipline to organize and coordinate teaching well; (2) Select teaching content, and select disciplines based on content; (3) Selected teaching cases to ensure that goals are achieved. This study is based on the integration of PBL teaching model.

\section{PBL Teaching Method Application Exploration}

\subsection{Information}

In this paper, 108 students in two classes in the medical examination department of a medical college are divided into two groups. One group will implement the discipline-integrated PBL teaching model, and one group will implement the traditional teaching model. 54 students under the PBL teaching model served as the observation group and 54 students under the traditional teaching model were used as the control group. There was no significant difference between the two groups of students in the general data $(\mathrm{P}>0.05)$, and they were comparable.

\subsection{Methods}

Both the control group and the experimental group used the book "Microbiological Examination" published by the People's Health Publishing House in 2010. The lecturer remained unchanged and used the same teaching plan to determine the same teaching difficulty points, theoretical class hour 64 , and experimental class hour 44 . In the process of implementing the teaching using the PBL teaching model, the teacher should divide the students into several groups of 8-10 people each [6]. The instructors guide the group work, question and inspire the student's reasoning process, allow the students to judge the information, and help the students to coordinate and integrate the basic knowledge and practical skills in the process of problem discussion.

\subsection{Observation indicators}

For this experimental study, the two groups of students performed meticulous observations and comprehensive records on the satisfaction of teaching mode, grade failure rate, achievement rate, and average score, providing data foundation and guarantee for experimental statistics and analysis.

Students' satisfaction with the teaching mode was conducted by questionnaires. Satisfaction with the teaching mode scores was 90 points or more; scores for the teaching modes were basically satisfied at 60-90 points; unsatisfactory with the teaching modes scored below 60 points., Satisfaction of teaching model $=($ Satisfaction number + basic satisfaction number) / total number of people.

Students scored 90 points or more for excellent results; students scored less than 90 points for failing grades; achievement rate = excellent number/total number; failing grade rate $=$ failed number/total number of cases.

\subsection{Statistical Analysis}

SPSS 20.0 statistical software was used to process the data statistically. The count data was expressed as percentage (\%). The $\mathrm{x} 2$ test was used. $\mathrm{P}<0.05$ was considered statistically significant.

\section{RESULTS}

\subsection{Questionnaire analysis}

54 students in the observation group were significantly more satisfied with the teaching model than the 54 students in the control group, and the 
difference was statistically significant $(\mathrm{P}<0.05)$.

Table 2: Questionnaire analysis

\begin{tabular}{|llllll|}
\hline Groups & $\begin{array}{l}\text { Num } \\
\text { ber of } \\
\text { cases }\end{array}$ & $\begin{array}{l}\text { Satisfac } \\
\text { tion }\end{array}$ & $\begin{array}{l}\text { Basic } \\
\text { ally } \\
\text { satisfi } \\
\text { ed }\end{array}$ & $\begin{array}{l}\text { Not } \\
\text { satisf } \\
\text { ied }\end{array}$ & $\begin{array}{l}\text { Satisfac } \\
\text { tion } \\
\text { rate }\end{array}$ \\
\hline $\begin{array}{l}\text { Observa } \\
\text { tion } \\
\text { group }\end{array}$ & 54 & 27 & 26 & 1 & $98 \%$ \\
$\begin{array}{l}\text { Control } \\
\text { group }\end{array}$ & 54 & 24 & 26 & 4 & $92 \%$ \\
\hline
\end{tabular}

The data in the table can be seen in the use of the discipline-integrated PBL teaching model due to the traditional teaching model.

\subsection{Student test results analysis}

Table 3: Student test results analysis

\begin{tabular}{|lllll|}
\hline Groups & $\begin{array}{l}\text { Number } \\
\text { of cases }\end{array}$ & $\begin{array}{l}\text { Excellent } \\
\text { results } \\
\text { (number } \\
\text { of cases) }\end{array}$ & $\begin{array}{l}\text { Failed } \\
\text { results } \\
\text { (number } \\
\text { of cases) }\end{array}$ & $\begin{array}{l}\text { Average } \\
\text { grade } \\
\text { (points) }\end{array}$ \\
\hline $\begin{array}{l}\text { Observation } \\
\text { group } \\
\begin{array}{l}\text { Control } \\
\text { group }\end{array}\end{array}$ & 54 & 13 & 5 & 82.5 \\
\hline
\end{tabular}

The data in the table can be seen in the use of the discipline-integrated PBL teaching model due to the traditional teaching model.

\section{CONCLUSION}

The unique superiority of the PBL teaching model has been widely adopted in foreign universities and has achieved extensive results. Major universities and colleges in China are also actively adopting and promoting this teaching method. It is a major advancement in medical education reform. It has promoted the reform of higher medical education concepts, the reconstruction of curriculum systems, the innovation of teaching methods, and the reconstruction of teaching evaluations, thus greatly promoting the development of medical science research and education. Human health requires the contribution of highly qualified medical personnel. The article outlines the development of PBL teaching, sums up the implementation of PBL teaching model in medical colleges and universities, and takes the medical students of a university as the research object, and compares the differences and advantages of PBL teaching methods with traditional teaching methods. In order to promote the reform of higher medical education concept, the reconstruction of curriculum system and the innovation of teaching methods provide new ideas. However, due to the fact that China's education system and teaching process are quite different from those of foreign countries, the implementation of PBL still faces some difficulties, such as lack of teacher experience, lack of teachers, lack of teaching resources, difficulty for some students, and the change of teaching mode and role of teachers and students. Adaptation, lack of scientific and effective evaluation system, etc. should be based on different teaching content, learning stage, and student quality, and reasonable selection of different teaching models, so that "according to the class system", to create a PBL teaching model suitable for China's national conditions.

\section{REFERENCES}

[1] Weiping, Y., Wanguang, C. 2010. Application of PBL teaching model in the teaching reform of colleges and universities. China Science and Technology Information, 13, 264.

[2] Takkunen, M., Turpeinen, H., Viisanen, H., Wigren, H.K., Aarnio, M., Pitkäniemi, J. 2011. Introduction of real patients into problem-based learnirg in preclinical first-year anatany curriculum. Med Teach, 33 (10), 854-856.

[3] Jianya, H., Junling, W., Xiaojie, L. 2016. Application of integrated teaching method of TBL, PBL and CBL in clinical teaching of oral prosthetics for undergraduates. Journal of Dalian Medical University, 38 (5), 483-486.

[4] Yang, W.C., Yamei, W., Xiaomei, Y. 2015. Taking the opportunity of international accreditation of medical education to explore the establishment of a biochemical quality assessment system. Basic Medical Science and Clinical, 17 (2), 278-280.

[5] Chaoyang, W., Yanzhi, H., Huiping, M. 2013. Exploration and practice of biochemistry experimental teaching innovation system in undergraduate teaching of traditional Chinese medicine. Basic Medicine and Clinical, 33 (12).

[6] Yanhong, H., Xiaolei, M., Anfang, C. 2010. Application of PBL. teaching method in biochemistry teaching. China Higher Medical Education, 201 (9), 122-123 